УДК 621.774 .33

Мироненко А. Ю.

\title{
КОНСТУКТИВНІ ОСОБЛИВОСТІ ОБЛАДНАННЯ ДЛЯ ТЕПЛОГО РОТАЦІЙНОГО КУВАННЯ ПРЕЦЕЗІЙНИХ ТРУБ ЗІ СПЛАВІВ НА ОСНОВІ МОЛІБДЕНУ
}

Прецизійні труби зі сплавів молібдену здебільш використовуються в обладнанні спеціального призначення, пов'язаному з ракетною технікою й атомною енергетикою. При цьому, граничні відхилення окремих видів зазначених труб за внутрішнім діаметром не повинні перевищувати 0,01 мм, при цьому поле допуску знаходиться в одній стороні $-0,01$ мм. Слід відзначити, що сплави на основі молібдену можливо піддавати пластичній деформації тільки при підвищених температурах, одночасно з цим вони характеризуються схильністю до газонасичення при термічній обробці. Традиційними технологіями з використанням станів ХПТР труби з такими допусками виготовити край складно [1].

Виходячи з технічних характеристик сучасних станів ХПТР [2, 3] труби зовнішнім діаметром менш ніж 6 мм, а особливо зі сплавів на основі молібдену, виготовляють методом волочіння як на оправці, так і без неї. Волочіння без оправки характеризується високою точністю зовнішнього діаметру труб. Для отримання високої точності за внутрішнім діаметром застосовується оправочне волочіння. Однак отримання зазначених труб зі сплавів на основі молібдену неможливе в зв'язку з тим, що для забезпечення процесу деформації потрібно нагрівати як трубу, що деформується, так і робочий інструмент до $450-500^{\circ} \mathrm{C}$. За таких температур міцність стрижня, що утримає оправку, стає низькою, й волочіння буде супроводжуватися постійними його обривами. Волочіння на рухомій (довгій) оправці теж не забезпечує необхідну точність готових труб в зв'язку з тим, що під час зняття труби з оправки, перша підлягає багаторазовому обкатуванню на обкатній машині, при цьому поперечний переріз труби стає багатогранним, овалізується.

Наразі перспективним є напрям використання способу редукування труб на станах ХПТР [4], але при застосуванні його для виготовлення молібденових труб прогнозованим буде їх руйнація за рахунок нерівномірності деформації по периметру труби під час прокатування.

Метою статті $є$ вибір способу виробництва прецизійних труб зі сплавів на основі молібдену, в тому числі й з профільними отворами (не круглими), а також визначення конструктивних особливостей деформаційного обладнання.

Аналіз технологій виробництва труб показує, що використання радіальнообтискувальних або ротаційно-кувальних машини для цього є виключенням. Зазвичай такі машини застосовуються лише для проміжної операції - при забивці головок перед волочінням.

Радіальний обтиск являє собою засіб обробки металів тиском, при якому заготовку (пола трубна заготовка), піддають пульсуючому обтиску бойками під дією радіальних сил таким чином, щоб деформація розповсюджувалася рівномірно по периметру поперечного перерізу заготовки на невеликій ділянці їі довжини. Для отримання високої якості зовнішньої поверхні заготовка обертається навколо своєї осі (можливо обертання бойків навколо заготовки), а пересування заготовки вздовж осі забезпечує іiі обробку по всій довжині.

Для радіального обтиску характерно деформування по схемі близької до тристороннього стискування, що дозволяє значно підвищити пластичність крихких матеріалів. При цьому, пульсуючі навантаження забезпечують зниження необхідних зусиль деформування, що дозволяє успішно використовувати радіальний обтиск для виготовлення труб із важкодеформованих матеріалів і сплавів. 
Процес радіального обтиску характеризується також загальним ступенем деформації за один прохід. Ця особливість процесу радіального обтиску цікава для використання ії при виготовлені труб з профільним (не круглим) отвором, що дозволило б зменшити циклічність виробництва, та зменшити витрати на виготовлення.

Весь процес радіального обтиску складається з більшої кількості окремих обтиснень, на долю яких доводиться порівняно мала ступінь деформації, що суттєво має облегшити умови деформування труб зі сплавів на основі молібдену.

В основі дії існуючих ротаційно-кувальних машин знаходиться жорсткий кінематичний зв'язок між роликами, бойками, плашками (штампами) та заготовкою. Для отримання виробів циліндричної форми, i, зокрема, труб, застосовуються ротаційно-кувальні машини, в яких положення штампів обумовлено ходом бойків та не регулюється в радіальному напрямку. 3 огляду на те, що матеріали, котрі підлягають обробці, мають різний опір деформації, зазор між штампами, який обумовлює розмір поперечного перерізу труби, $є$ таким, що не може бути визначений заздалегідь. Крім того, на величину зазору впливає й ряд технологічних обставин: величина подачі, температура нагріву заготовки, число обертів шпинделя та ін. Відсутність регулювання зазору проміж штампами не дає можливості вносити корективи в його величину, що не дозволяє отримувати труби з підвищеними допусками. Крім того, існуючі машини не обладнані системою нагріву заготовки та технологічного інструменту, що не дозволяє деформувати на них труби з крихких сплавів.

В рамках даної роботи була модернізована існуюча конструкція ротаційно-кувальної машини (рис. 1).

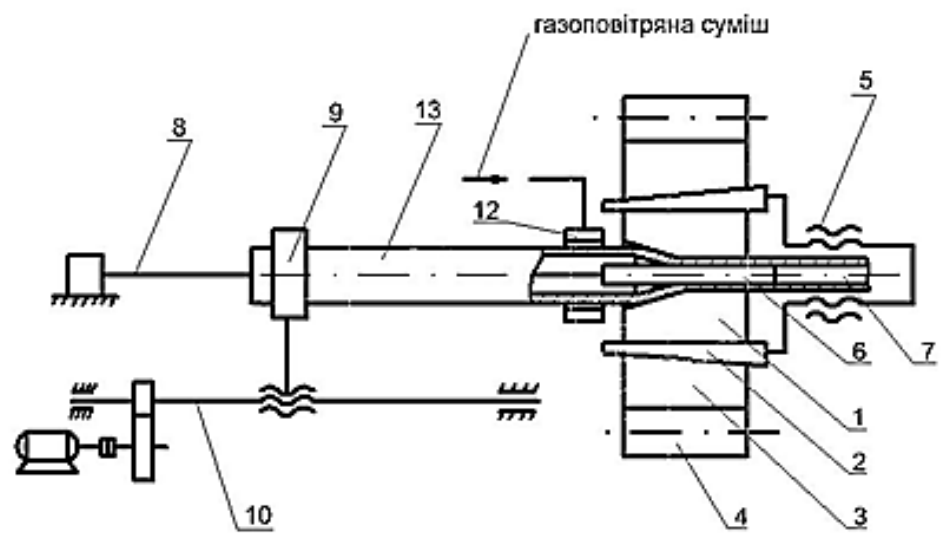

Рис. 1. Принципова схема модернізованої ротаційно-кувальної машини:

1 - плашки для деформування заготовки; 2 - клини; 3 - бійки; 4 - ролики сепаратора, що обертається; 5 - механізм пересування клинів; 6 - оправка; 7 - готова труба; 8 - стрижень оправки; 9 - патрон подачі заготовки; 10 - механізм подачі; 11 - привід механізму подачі; 12 - газова горілка для нагріву заготовки та плашок; 13 - заготовка

Модернізація машини полягала в установці газової горілки для підігріву заготовки та робочого інструменту - використання саме такого способу забезпечує необхідні температурні умови для процесу радіального кування сплавів на основі молібдену, установку механізму подачі труби з необхідним регулюванням ступенів подачі, та встановлення клинового механізму для регулювання зазорів між плашками.

Модернізована ротаційно-кувальна машина працює наступним чином. Заготовка 13, яка закріплюється в патрон подачі 9, за допомогою механізму подачі 10, подається скрізь газову горілку 12 в робочий отвір ротаційно - кувальної машини. Шпиндель, який обертається у сепараторі, за допомогою роликів 4, що накатуються на бійки 3 , примушує пересуватися бійки 3, клини 2 та плашки 1 у радіальному напрямку. Плашки 1 б ють по заготовці 13, деформують іiі на нерухомій оправці 6 до необхідного розміру. Кількість ударів бойків 
регулюється за рахунок зміни кількості обертів шпинделя. Необхідний діаметр труб встановлюється за допомогою механізму пересування клинів, що змінюють величину зазорів проміж плашками. Величина подачі заготовки регулюється шляхом зміни кількості обертів гвинта подачі. Передбачено обмеження величини подачі за один удар бойків за допомогою планок, які не дозволяють збільшувати зазор між плашками більш розрахованої величини.

Основні технічні дані та характеристики ротаційно-кувальної машини наведені в табл. 1.

Таблиця 1

Основні технічні дані та характеристики ротаційно-кувальної машини

\begin{tabular}{|l|c|}
\hline \multicolumn{1}{|c|}{ Найменування параметрів } & Значення \\
\hline Номінальне зусилля, кН & 100 \\
\hline Частота обертів шпинделя, хв ${ }^{-1}$ & $0-1000$ \\
\hline Кількість бойків, шт & 2 \\
\hline Величина ходу бойка, мм & $0,5-2,0$ \\
\hline Частота ударів бойка за один оберт шпинделя & 5 \\
\hline Швидкість подачі заготовки, м/с & До 0,005 \\
\hline Величина подачі за цикл (якщо кут вхідного конусу & До 1,0 \\
плашок = $15^{0}$, мм & 12 \\
\hline Найбільший діаметр заготовки, мм & $1,0-10$ \\
\hline Діаметр готових труб, мм & До 600 \\
\hline Температура нагріву заготовки, ${ }^{0} \mathrm{C}$ & До 0,95 \\
\hline Продуктивність при обтиску труб розміром & \\
$3,3 \times 0,3$ мм, м/хв & \\
\hline
\end{tabular}

3 використання вищезазначеного способу і обладнання в умовах ДП “НДТІ” було виготовлено декілька партій прецизійних труб зі сплаву на основі молібдену з високою точністю за внутрішнім діаметром. Зокрема й труби з профільними (не круглими) отворами. Зазначену трубну продукцію раніше на території колишнього СРСР технічно не було можливості виготовляти.

\section{ВИСНОВКИ}

Підводячи підсумок викладеному у статті матеріали варто зауважити наступне.

1. Найбільш раціональним способом виготовлення прецизійних труб зовнішнім діаметром менше 6 мм, в тому числі і труб з профільним (не круглим) отвором, зі сплавів на основі молібдену є їх теплий радіальний обтиск з використанням ротаційно-кувальних машин.

2. Для теплого радіального обтиску труб зі сплавів на основі молібдену можливо використовувати існуючі ротаційно-кувальні машини з урахуванням їх модернізації: встановлення механізму подачі заготовки, а також газових горілок для нагріву заготовки й кувальних плашок.

\section{СПИСОК ВИКОРИСТАНОЇ ЛІТЕРАТУРИ}

1. Король Р. Н. Развитие направлений повышения точности и качества прецизионных тонкостенных и особотонкостенных труб при холодной периодической роликовой прокатке / Р. Н. Король // Металл и литье Украиныл. - 2008. - № 3-4. - C. 44-51.

2. Король Р. Н. Резервы повышения точности труб, прокатанных на станах холодной периодической роликовой прокатки (ХПТР) / Р. Н. Король, И. М. Амиров // Металл и литье Украины. - 2007. - № 5. - С. 54-59.

3. Король Р. Н. Особенности калибровки рабочего инструмента станов ХПТР для прокатки особотонкостенных труб повышенной точности по внутреннему диаметру и толщине стенки / Р. Н. Король // Металл и литье Украины. - 2007. - № 8. - С. 24-27.

4. Король Р. Н. Рациональная технология уменьшения разностенности на тонкостенных и особотонкостенных трубах / Р. Н. Король // Металл и литье Украины. - 2007. - № 9-10. - С. 47-50. 